\title{
Pembaharuan Hukum Pidana di Indonesia yang Berkeadilan Gender dalam Ranah Kebijakan Formulasi, Aplikasi, dan Eksekusi
}

\author{
Criminal Law Reform in Indonesia with Gender Equity in Domain of \\ Formulation, Application and Execution Policy
}

\author{
Vivi Ariyanti \\ Fakultas Syariah IAIN Purwokerto \\ E-mail: viviariyanti@iainpurwokerto.ac.id
}

\begin{abstract}
The law is the main tool used to regulate the life of society and the state. However, due to the development of society and also urged by the need for increasingly complex social life in the present, especially with regard to the values of gender justice, the law must follow the direction of community development. The legal renewal (amendment of laws) is inseparable from the concept of legal reform whose scope is very broad, because legal reform does not only mean renewal of laws and regulations. Legal reform covers the whole legal system, namely reform of the legal substance, legal structure, and legal culture. This paper seeks to examine how the direction of reform of Indonesian criminal law with gender equity as an effort to answer the challenges of the times and also accommodate the aspirations of the Indonesian people in general. Crime prevention based on gender inequality, namely sexual violence, can be done by means of a penal policy through formulation policies, application policies, and execution policies. Formulation policies are used to realize laws that have a gender perspective and prioritize gender justice. Laws governing criminal law can be designed using a special concept (lex specialis) which regulates criminal acts of sexual violence, both in terms of material and formal law. As for the application policy, the reform model is carried out by the legal apparatus working together with the community, by having a joint commitment in fighting all forms of crime based on gender inequality. Whereas in the execution policy, the government is demanded to be firm and without discriminatory attitudes based on gender or views that demean women in carrying out lawsuits that have been formulated or decided by the court.
\end{abstract}

Keyword: Renewal; Criminal law; Gender perspective

Abstrak: Hukum merupakan alat utama yang digunakan untuk mengatur tata kehidupan bermasyarakat dan bernegara. Namun demikian, disebabkan karena 
perkembangan masyarakat dan juga didesak oleh kebutuhan semakin kompleksnya kehidupan sosial di masa sekarang, terutama berkaitan dengan nilai-nilai keadilan gender, hukum harus mengikuti arah perkembangan masyarakat. Pembaharuan hukum tidak lepas dari konsep tentang reformasi hukum yang cakupannya sangat luas, karena reformasi hukum tidak hanya berarti pembaharuan peraturan perundang-undangan. Reformasi hukum mencakup sistem hukum secara keseluruhan, yaitu reformasi substansi hukum, struktur hukum, dan budaya hukum. Tulisan ini berusaha mengkaji bagaimana arah pembaharuan hukum pidana Indonesia yang berkeadilan gender sebagai upaya untuk menjawab tantangan zaman dan juga mengakomodasi aspirasi masyarakat Indonesia pada umumnya. Penanggulangan tindak pidana yang didasarkan atas ketimpangan gender, yaitu kekerasan seksual, dapat dilakukan dengan sarana penal (penal policy) melalui kebijakan formulasi, kebijakan aplikasi, dan kebijakan eksekusi. Kebijakan formulasi digunakan untuk mewujudkan hukum yang berperspektif gender dan mengutamakan keadilan gender. Undang-undang yang mengatur hukum pidana dapat dirancang menggunakan konsep khusus (lex specialis) yang mengatur tindak pidana kekerasan seksual, baik dari aspek hukum materiil maupun hukum formil. Adapun kebijakan aplikasi, model pembaharuannya dilakukan oleh aparatur hukum dan dapat bekerja sama dengan masyarakat, dengan memiliki komitmen bersama dalam melawan segala bentuk tindak pidana yang berbasis ketimpangan gender. Sedangkan dalam kebijakan eksekusi, pemerintah dituntut untuk tegas dan tanpa ada sikap diskriminatif berdasarkan gender maupun pandangan yang merendahkan perempuan dalam melaksanakan tuntutan hukum yang telah diformulasikan maupun yang diputuskan oleh pengadilan.

Kata kunci: Pembaharuan; hukum pidana; perspektif gender

\section{PENDAHULUAN}

Isu-isu hukum di masa kontemporer semakin menggambarkan bagaimana keadilan masyarakat dapat dilihat dari berbagai aspek, salah satunya adalah aspek keadilan gender. Rasa keadilan sering kali dikaitkan dengan status gender seorang korban tindak pidana, terutama perempuan, karena perempuan merupakan satu elemen masyarakat yang dipandang paling lemah dan paling rentan untuk menjadi korban suatu tindak pidana. Di sisi lain, perempuan juga dipandang lebih sulit untuk mengakses keadilan jika kasus yang menimpanya berkaitan dengan tindak pidana kekerasan seksual. Misalnya kasus tindak pidana perkosaan yang sering kali pelakunya lolos dari jerat hukum karena kurangnya alat bukti dan tidak adanya saksi, ancaman pidana bagi korban pemerkosaan yang melakukan aborsi, viktimisasi dan penyalahan terhadap perempuan korban kekerasan seksual merupakan contoh-contoh lain dalam permasalahan yang dihadapi perempuan di Indonesia saat mencari keadilan hukum. Bukannya mendapatkan keadilan seperti yang diharapkan, banyak dari perempuan yang malah kembali menjadi korban akibat sistem 
hukum yang tidak berpihak pada perempuan korban, dan aparat penegak hukum yang tidak memiliki perspektif kesetaraan gender. Contoh lain yang menjadi perhatian publik akhir-akhir ini adalah kasus yang menimpa Baiq Nuril, yang menyebabkan keadilan publik terusik saat mendengar putusan kasasi yang dijatuhkan Mahkamah Agung terhadapnya menyatakan dia bersalah telah menyebarkan rekaman bermuatan pelanggaran kesusilaan dan mengakibatkan dia dijatuhi hukuman enam bulan penjara serta denda 500 juta Rupiah, sebagaimana tertuang dalam putusan kasasi Mahkamah Agung Nomor 574K/Pid.Sus/2018.

Publik terusik rasa keadilannya disebabkan karena beranggapan bahwa Baiq Nuril diperlakukan tidak adil lantaran dia sesungguhnya adalah korban pelecehan seksual yang dilakukan oleh oknum atasannya di suatu tempat kerja. Nuril dilaporkan atasannya tersebut dengan menggunakan dasar Pasal 27 Ayat (1) UU No. 11/2008 jo. UU No. 19/2016 tentang Informasi dan Transaksi Elektronik (ITE). Beredarnya rekaman bermuatan pelanggaran kesusilaan tersebut dibebankan kepada Nuril, padahal rekaman itu disebarkan oleh rekannya, tetapi justru Nuril yang dilaporkan oleh mantan atasannya tersebut. $^{1}$

Sebagai negara hukum, Indonesia melalui aparat penegak hukum memang sudah seharusnya memandang bahwa setiap tindakan dan akibatnya yang dilakukan oleh semua pihak di negara ini harus berdasarkan atas hukum. Hukum merupakan alat utama yang digunakan untuk mengatur tata kehidupan bermasyarakat dan bernegara. Namun demikian, disebabkan karena perkembangan masyarakat dan juga didesak oleh kebutuhan semakin kompleksnya kehidupan sosial di masa sekarang, hukum harus mengikuti arah perkembangan masyarakat tersebut, termasuk di dalamnya adalah perkembangan nilainilai keadilan yang didasarkan pada aspek kesetaraan gender.

Hukum yang berlaku di Indonesia, banyak yang berasal dari peninggalan pemerintahan penjajah Belanda, misalnya Kitab Undang-Undang Hukum Pidana (KUHP) yang dibuat di awal abad ke-19 dan sering kali bertentangan dengan kondisi sosial bangsa Indonesia di masa kontemporer saat ini. Hal ini tentu membutuhkan upaya penyesuaian dengan tingkat kemajuan masyarakat, sehingga hukum pidana di Indonesia memerlukan upaya-upaya pembaharuan. Dengan demikian, ide pembaharuan dan pengembangan hukum pidana nasional pada hakikatnya tidak terlepas dari pertimbangan politis, filosofis,

1 W. Riawan Tjandra. “Mengukur Rasa Keadilan Putusan Kasus Baiq Nuril”, Kompas, 17 Juli 2019, hlm. 6. 
sosiologis dan pertimbangan praktis lainnya sebagai alasan dilakukan pembaharuan hukum pidana nasional.

Menurut Barda Nawawi Arief perkembangan aturan umum KUHP sejak berlakunya UU No. 1 Tahun 1946 tentang Peraturan Hukum Pidana hingga saat ini, tidak mengalami perubahan yang mendasar, karena pada dasarnya prinsip-prinsip umum (general principle) hukum pidana dan pemidanaan yang ada dalam KUHP masih seperti pada WvS Hindia Belanda. ${ }^{2}$

Pembaharuan hukum tidak lepas dari konsep tentang reformasi hukum yang cakupannya sangat luas, karena reformasi hukum tidak hanya berarti pembaharuan peraturan perundang-undangan. Reformasi hukum mencakup sistem hukum secara keseluruhan, yaitu reformasi substansi hukum, struktur hukum, dan budaya hukum. ${ }^{3}$ Pembaharuan hukum pidana pada hakikatnya merupakan suatu upaya melakukan peninjauan dan pembentukan kembali (reorientasi dan reformasi) hukum pidana yang sesuai dengan perkembangan nilai-nilai sosio-politik dan sosio-kultural masyarakat Indonesia. Karena itu, penggalian nilai-nilai masyarakat dalam usaha pembaharuan hukum pidana Indonesia harus dilakukan agar hukum pidana Indonesia masa depan sesuai dengan kondisi terkini dari sosio-politik dan sosio-kultural masyarakat Indonesia. Pada pelaksanaannya penggalian nilai ini bersumber pada hukum pidana positif, hukum adat, hukum agama, hukum pidana negara lain, serta kesepakatan-kesepakatan internasional mengenai materi hukum pidana. Hukum agama, terutama yang dianut secara mayoritas, yakni Islam, perlu menjadi sumber bagi pembaharuan hukum modern dan kontemporer karena penafsiran atas hukum agama juga mengikuti perkembangan masyarakat. ${ }^{4}$

Tulisan ini berusaha mengkaji bagaimana arah pembaharuan hukum pidana Indonesia yang lebih berkeadilan gender sebagai upaya untuk menjawab tantangan zaman dan juga mengakomodasi aspirasi masyarakat Indonesia pada umumnya. Tulisan ini juga membahas politik hukum pidana sebagai bagian dari usaha pembaharuan hukum. Dalam menyongsong pembaharuan hukum pidana Indonesia, maka perlu adanya diskusi-diskusi yang memberikan wacana alternatif untuk penyempurnaan hukum pidana yang

2 Barda Nawawi Arief, RUU KUHP Baru Sebuah Resrukturisasi/Rekonstruksi Sistem Hukum Pidana Indonesia. Semarang: Badan Penerbit Universitas Diponegoro, 2009, hlm. 4

3 Barda Nawawi Arief, Bunga Rampai Kebijakan Hukum Pidana (Perkembangan Penyusunan Konsep KUHP Baru. Bandung: Citra Aditya Bakti, 2014, hlm. 6.

4 Bani Syarif Maula, Sosiologi Hukum Islam di Indonesia: Studi tentang Realitas Hukum Islam dalam Konfigurasi Sosial dan Politik. Malang: Aditya Media Publishing, 2010, hlm. 10. 
berkeadilan gender.

\section{ANALISIS DAN PEMBAHASAN}

\section{Kesetaraan Gender dalam Pembaharuan Hukum Pidana}

Tuntutan kesetaraan gender merupakan kenyataan yang harus dihadapi di hampir semua aspek kehidupan masyarakat. Hal ini disebabkan karena posisi perempuan di masa lalu dianggap termarginalkan, tidak dipandang sejajar dengan kaum laki-laki, bahkan tidak mempunyai hak mengambil keputusan. Hal ini bermula dari budaya patriarki yang menanamkan pemahaman bahwa wilayah publik merupakan wilayah laki-laki, sehingga kiprah perempuan di ranah publik secara umum berada pada posisi subordinat laki-laki. Begitu juga jika seorang perempuan sedang berhadapan dengan proses hukum. Terkadang perempuan merasa sulit untuk membela dirinya sendiri jika kasus yang menimpanya berkaitan dengan kekerasan seksual (tindak kekerasan yang didasarkan pada ketidaksetaraan gender). Di sinilah letak pentingnya upaya pembaharuan hukum pidana yang dapat menyerap aspirasi nilai-nilai baru dalam masyarakat untuk mewujudkan kesetaraan dan keadilan gender di depan hukum.

Pembaharuan hukum pidana pada hakikatnya merupakan suatu upaya melakukan peninjauan dan pembentukan kembali (reorientasi dan reformasi) hukum pidana yang sesuai dengan perkembangan nilai-nilai sosio-politik dan sosio-kultural masyarakat Indonesia. Karena itu, penggalian nilai-nilai masyarakat dalam usaha pembaharuan hukum pidana Indonesia harus dilakukan agar hukum pidana Indonesia di masa depan sesuai dengan kondisi terkini dari sosio-politik dan sosio-kultural masyarakat Indonesia. Pada pelaksanaannya penggalian nilai ini bersumber pada hukum adat, hukum pidana positif, hukum agama, hukum pidana negara lain, serta kesepakatan-kesepakatan internasional mengenai materi hukum pidana.

Hukum pidana adalah bagian dari sistem hukum atau sistem norma. Sebagai suatu sistem, hukum pidana memiliki sifat umum dari suatu sistem, yaitu menyeluruh (wholism), memiliki beberapa unsur (elements), semua elemen saling terkait (relations) dan kemudian membentuk struktur (structure). Lawrence W. Friedman membaginya menjadi tiga elemen, yaitu elemen struktural (structure), elemen substansi (substance), dan elemen budaya hukum (legal culture)..$^{5}$

5 Lawrence M. Friedman, Sistem Hukum Perspektif Ilmu Sosial, cet. 7, terj. M. Khozim. Bandung: Nusamedia, 2015, hlm. 12-18. 
Pembaharuan hukum dalam suatu sistem hukum mencakup empat aspek pokok dari sistem hukum, yaitu: 1) aspek filosofis, yakni adanya nilai yang mendasari sistem hukum; 2) aspek asas-asas hukum; 3) aspek normatif, yakni adanya norma atau hukum/peraturan perundang-undangan; dan 4) aspek sosiologis, yakni masyarakat hukum sebagai pendukung sistem hukum tersebut. Keempat aspek dasar ini tersusun dalam suatu rangkaian satu kesatuan yang membentuk suatu sistem substantif hukum (nasional). ${ }^{6}$

Esensi pembaruan hukum adalah bagaimana memperbaharui hukum dalam suatu sistem hukum agar keempat aspek pokok di atas berada dalam satu kesatuan atau memiliki jalinan yang menyatukan. Pengertian kesatuan di sini dimaksudkan agar keempat aspek tersebut menjadi satu untuk keseluruhan atau menyeluruh (wholism), saling terkait (relation) dan membentuk struktur (structure). ${ }^{7}$ Oleh sebab itu, pembaharuan hukum yang tidak mengubah makna substantif hanya memiliki pengaruh yang sangat terbatas karena pembaruan yang demikian ini dikatakan hanya mengganti rumusan kata-kata yang lama dengan rumusan kata-kata yang baru. Sebaliknya, apabila pembaharuan itu sampai pada mengubah atau mengganti aspek substantif dari sistem hukum yang lama, maka pembaharuan tersebut akan mempengaruhi elemen sistem hukum secara menyeluruh.

Pembaharuan hukum pidana harus dimulai dari pembaharuan hukum (peraturanperaturan) tertulis yang berasal dari kaidah-kaidah hukum dan norma-norma yang hidup dalam masyarakat, yang di dalamnya ada norma-norma baru bagi masyarakat kontemporer, yaitu norma kesetaraan gender. Pembaharuan hukum berikutnya harus dapat menyentuh aspek hukum yang konkret dan khusus, yaitu hukum telah diterapkan/diberlakukan pada kasus yang tertentu. Pengadilan melalui putusan-putusan hakim berperan mentransformasikan ide-ide yang bersumber pada nilai-nilai moral yang bersifat abstrak ke dalam peristiwa konkret, sehingga putusan hakim memvisualisasikan asas-asas yang abstrak menjadi kaidah hukum konkret. Misalnya kebijakan pidana terhadap tindak pidana pemerkosaan, dalam hal seorang perempuan yang menjadi korbannya berada dalam suatu tempat dan waktu yang rentan hanya karena dia seorang

\footnotetext{
6 Mudzakir, Posisi Hukum Korban Kejahatan dalam Sistem Peradilan Pidana. Disertasi, Jakarta: Program Pascasarjana Fakultas Hukum Universitas Indonesia, 2001, hlm. 284.

$7 \quad$ Ibid., hlm. 286.
} 
perempuan. ${ }^{8}$ Kondisi yang menempatkan perempuan menjadi rentan tersebut harus menjadi perhatian dan pertimbangan hukum. Dengan demikian, pembaharuan hukum pidana juga dapat dilakukan oleh hakim dalam menyelesaikan suatu kasus pidana di persidangan. Hal ini disebabkan karena wilayah penentuan pidana merupakan wilayah otoritas hakim, bahkan pada wilayah ini tidak seorang pun dapat mempengaruhi kehendak hakim dalam menentukan seberapa besar pidana yang pantas dijatuhkan kepada terdakwa. Tidak heran jika dalam suatu pemidanaan sering terjadi disparitas pidana, karena ukuran pemidanaan dari masing-masing hakim tidak akan sama, karena wilayah hati nurani merupakan wilayah paling abstrak dalam suatu dimensi kewenangan.

Membatasi kebebasan hakim dalam mengekspresikan logika-logika hukum terhadap setiap kasus tertentu pada akhirnya hanya akan menghambat upaya proses pencarian nilai-nilai keadilan yang sebenarnya, walaupun kebebasan itu bukan berarti dapat dilakukan sebebas-bebasnya tanpa disertai dengan tanggung jawab secara yuridis, misalnya kasus-kasus tindak pidana pemerkosaan atau tindak pidana kekerasan seksual lainnya yang korbannya lebih sering perempuan. Penegakan hukum terhadap kejahatan seksual sudah seharusnya dilakukan secara tegas, komprehensif, berkesinambungan, dan dengan terobosan-terobosan hukum (dengan cara-cara luar biasa), ${ }^{9}$ termasuk dengan memperhatikan nilai keadilan gender.

Perhatian terdapat aspek keadilan gender tersebut dapat dipandang sebagai bentuk pengayoman. Mudzakir menyatakan bahwa konsep pengayoman ini telah mempengaruhi cara pandang terhadap hukum pidana yang lebih memanusiakan, di mana pidana penjara dan institusi penjara diberi makna baru, yaitu pemasyarakatan dan institusinya disebut Lembaga Pemasyarakatan. ${ }^{10}$ Ide pengayoman tersebut telah memberikan perspektif baru dalam hukum pidana dan pemidanaan serta penyelenggaraan sistem peradilan pidana. Hukum pidana dan penyelenggaraan peradilan dalam konsep pengayoman berarti melindungi atau memberikan rasa aman kepada semua orang yang berkepentingan dengan hukum, terutama terhadap golongan masyarakat yang rentan dan lemah dalam mengakses keadilan, seperti perempuan yang menjadi korban

8 Vivi Ariyanti, "Konsep Perlindungan Korban dalam Sistem Peradilan Pidana Nasional dan Sistem Hukum Pidana Islam”, Al-Manahij: Jurnal Kajian Hukum Islam, 13 (1), 2019, hlm. 33-48.

9 Vivi Ariyanti, "Implementasi Asas Legalitas dan Retroaktiftentang Tindak Pidana Korupsi dalam Perspektif Hukum Islam”, Al-Manahij: Jurnal Kajian Hukum Islam, 9(1), 2015, hlm. 167-177.

10 Mudzakir, Posisi Hukum Korban Kejahatan dalam Sistem Peradilan Pidana. Disertasi, Jakarta: Program Pascasarjana Fakultas Hukum Universitas Indonesia, 2001, hlm. 287. 
tindak pidana kekerasan seksual. Konsep pengayoman juga sesuai dengan nilai-nilai masyarakat Indonesia, sehingga bila ada hukum (peraturan perundang-undangan) yang tidak sesuai dengan nilai-nilai yang hidup dalam masyarakat maka hukum tersebut perlu diubah (rule breaking). ${ }^{11}$

\section{Kebijakan Hukum Pidana Sebagai Fondasi Pembaharuan}

Wacana tentang pembaharuan hukum yang berkeadilan gender dapat membawa kita pada diskusi dan perdebatan tentang teori-teori hukum yang sangat beragam, namun jika dikaitkan dengan keadilan gender tentu ada satu teori hukum yang disebut teori hukum feminis. Teori Hukum Feminis atau Feminist Legal Theory muncul pertama kali pada tahun 1970-an, bersamaan dengan berkembangnya gerakan Critical Legal Studies di Amerika. Sebagai sebuah pemikiran yang berusaha melakukan terobosan terhadap berlakunya hukum terhadap perempuan dan diskriminasi yang didapat perempuan dari hukum. ${ }^{12}$

Tulisan ini tidak akan membahas Teori Hukum Feminis secara luas, namun ide dan tujuan dari pembaharuan hukum yang berperspektif gender tentu didasari oleh teori tersebut. Teori hukum feminis adalah pandangan yang melihat bahwa hukum berperan dalam menekankan subordinasi perempuan dan berupaya untuk melakukan pembaharuan posisi dan pendekatan hukum terhadap perempuan dan gender. ${ }^{13}$ Setidaknya terdapat lima hal yang dapat digaris-bawahi dari teori hukum feminis, yaitu antara lain: pengalaman perempuan, adanya bias gender secara implisit, jeratan/ikatan ganda dan dilema dari perbedaan, reproduksi model dominasi laki-laki, serta membuka pilihan-pilihan perempuan. Teori hukum feminis berpendirian bahwa hukum "berjenis kelamin laki-laki" karena pembuat hukum didominasi oleh laki-laki. Maka sebagaimana aliran hukum kritis, diskursus hukum kemudian melupakan suara dari pihak yang terpinggirkan, yang dalam konteks ini adalah perempuan. ${ }^{14}$ Oleh karena itu, pengkajian hukum menurut teori hukum feminis haruslah dilakukan dengan melandaskan diri pada pengalaman perempuan dan pembaharuan hukum harus melibatkan pandangan dari

11 Any Ismayawati, “Urgensi Nilai-nilai Religius dalam Pembaharuan Konsep Penanggulangan Pelacuran”, AlManahij: Jurnal Kajian Hukum Islam, 5 (2), 2011, hlm. 227-242.

12 Niken Savitri, HAM Perempuan Kritik Teori Hukum Feminis Terhadap KUHP, Jakarta: Refika Aditama, 2008, hlm. 27.

13 Martha A. Fineman, "Feminist Legal Theory”, Journal of Gender, Social Policy and the Law, Vol. 13 No. 1, 2015, hlm. 13-32.

14 Aditya Yuli Sulistyawan, "Feminist Legal Theory dalam Telaah Paradigma: Suatu Pemetaaan Filsafat Hukum”, Jurnal Masalah-Masalah Hukum, Vol. 47, No. 1, Januari 2018, hlm. 56-62. 
kaum perempuan. Pembaharuan hukum yang berkeadilan gender dalam sistem hukum pidana Indonesia dapat dilakukan dengan menggunakan pendekatan kebijakan hukum pidana.

Hukum pidana secara umum mengandung setidaknya dua jenis norma, yakni norma yang harus selalu dipenuhi agar suatu tindakan dapat disebut sebagai tindak pidana, dan norma yang berkenaan dengan ancaman pidana yang harus dikenakan bagi pelaku dari suatu tindak pidana. Secara terinci undang-undang hukum pidana telah mengatur tentang: 1) bilamana suatu pidana dapat dijatuhkan bagi seorang pelaku, 2) jenis pidana yang bagaimanakah yang dapat dijatuhkan bagi pelaku tersebut, 3) untuk berapa lama pidana dapat dijatuhkan atau berapa besarnya pidana denda yang dapat dijatuhkan, dan 4) dengan cara bagaimanakah pidana harus dilaksanakan. ${ }^{15}$

Konsep bahwa tindak pidana adalah melanggar kepentingan negara sebagai representasi kepentingan publik, umumnya menjadi dasar kewenangan negara untuk menentukan, membuat peraturan, menuntut, dan menghukum seseorang yang melanggar peraturan. Hal ini diperkuat oleh pengklasifikasian ilmu hukum di mana hukum pidana adalah bagian dari hukum publik yang tidak membolehkan campur tangan individu. ${ }^{16} \mathrm{Di}$ sinilah letak pentingnya kebijakan negara dalam kaitannya dengan penetapan aturan perundang-undangan hukum pidana. Dalam menentukan suatu tindak pidana digunakan kebijakan hukum pidana.

Kebijakan untuk membuat peraturan hukum pidana yang berkeadilan gender pada hakikatnya tidak dapat dilepaskan dari tujuan penanggulangan kejahatan terhadap perempuan, sehingga kebijakan hukum pidana juga merupakan bagian dari politik kriminal. Dengan kata lain, dilihat dari sudut politik kriminal, maka kebijakan hukum pidana identik dengan pengertian "kebijakan penanggulangan kejahatan dengan hukum pidana". ${ }^{17}$

Digunakannya hukum pidana sebagai sarana untuk menanggulangi kejahatan, tampaknya tidak menjadi persoalan bagi masyarakat Indonesia secara umum. Hal ini terlihat dari praktik perundang-undangan selama ini yang menunjukkan bahwa penggunaan hukum pidana merupakan bagian dari kebijakan atau politik hukum yang dianut di Indonesia. Penggunaan hukum pidana dianggap sebagai hal yang wajar dan

\footnotetext{
15 P.A.F. Lamintang dan Theo Lamintang, Hukum Penitensier Indonesia, edisi ke-2, cet. 2. Jakarta: Sinar Grafika, 2012, hlm. 1.

16 Mudzakir, "Kedudukan Korban Tindak Pidana dalam Sistem Peradilan Pidana Indonesia Berdasarkan KUHP dan RUU KUHP", Jurnal Ilmu Hukum, 14(1), 2011, hlm. 28-62.

17 Ibid., hlm. 28.
} 
normal, seolah-olah eksistensinya tidak lagi dipersoalkan. Namun demikian, yang menjadi masalah adalah garis-garis kebijakan atau pendekatan bagaimanakah yang sebaiknya ditempuh dalam menggunakan hukum pidana itu. ${ }^{18}$ Banyak kasus-kasus tindak pidana kekerasan seksual yang korbannya adalah perempuan justru susah dibuktikan dan bahkan aparat cenderung menyalahkan korbannya, misalnya dengan menyalahkan cara dia berpakaian, dan sebagainya.

Sudarto menyatakan bahwa apabila hukum pidana hendak digunakan seharusnya terlebih dahulu dilihat hubungannya dengan keseluruhan politik hukum pidana atau social defence planning yang merupakan bagian integral dari rencana pembangunan nasional. ${ }^{19}$ Politik hukum pidana merupakan pengaturan atau penyusunan secara rasional usaha-usaha pengendalian kejahatan oleh masyarakat. Tujuan akhir dari kebijakan hukum pidana ialah "perlindungan masyarakat" untuk mencapai tujuan utama berupa "kebahagiaan warga masyarakat" (happiness of the citizens), "kehidupan kultural yang sehat dan menyegarkan" (a wholesome and cultural living), "kesejahteraan masyarakat" (social welfare), dan untuk mencapai "kesetaraan" (equality). ${ }^{20}$

Pembaharuan hukum pidana dilihat dari sudut pendekatan nilai pada hakikatnya merupakan upaya melakukan peninjauan dan penilaian kembali (reorientasi dan reevaluasi) nilai-nilai sosiopolitik, sosiofilosofis dan sosiokultural yang melandasi dan memberi isi terhadap muatan normatif dan substantif hukum pidana yang dicita-citakan. ${ }^{21}$ Ruang lingkup reformasi hukum pidana (penal reform), sebagaimana reformasi hukum secara umum, tidak hanya terbatas pada pembaharuan undang-undang atau substansi hukum (legal substance reform), tetapi juga pembaharuan struktur hukum (Iegal structure reform), dan pembaharuan budaya hukum (legal culture reform) yang termasuk di dalamnya juga pembaharuan etika hukum dan ilmu/pendidikan hukum (legal ethic and legal science/education reform).22

Dari ketiga aspek pembaharuan hukum tersebut, menurut Barda Nawawi Arief, aspek pembaharuan budaya hukum (legal culture reform) harus diutamakan apabila sasarannya adalah penegakan keadilan, karena hakikat pembaharuan hukum bukan

18 Muladi dan Barda Nawawi Arief, Teori-Teori dan Kebijakan Pidana, cet. 4. Bandung: Alumni, 2010, hlm. 156-157.

19 Sudarto, Hukum Pidana dan Perkembangan Masyarakat. Jakarta: Sinar Baru, 1983, hlm. 20.

20 Ibid., hlm. 157-158.

21 Ibid., hlm. 30.

22 Barda Nawawi Arief, Masalah Penegakan Hukum dan Kebijakan Hukum Pidana dalam Penanggulangan Kejahatan. Jakarta: Kencana Media Group, 2007, hlm. 6. 
terletak pada aspek formal dan lahiriah (seperti terbentuknya undang-undang baru, struktur kelembagaan dan mekanisme/prosedur baru, bertambahnya bangunan dan sarana/prasarana lainnya yang serba baru), melainkan justru terletak pada aspek imaterial berupa budaya dan nilai-nilai kejiwaan dari hukum. ${ }^{23}$ Dalam hal ini penulis sependapat dengan Barda Nawawi Arief bahwa untuk melakukan pembaharuan hukum pidana yang berkeadilan gender harus lebih ditekankan pada aspek budaya hukum (legal culture) yang memperhatikan unsur keadilan dan kesetaraan gender, selain aspek substansi hukum (aturan perundang-undangan) yang juga perlu diperbaharui agar lebih memandang perempuan setara dengan laki-laki.

Uraian di atas menegaskan, bahwa aspek substansial, aspek struktural, dan aspek kultural pada hakikatnya merupakan kesatuan yang membentuk sistem peradilan pidana. Sistem merupakan sesuatu yang integral, sehingga pengertian sistem peradilan dapat dilihat dari ketiga aspek tersebut: substansi hukum (legal substance), struktur hukum (legal structure), dan budaya hukum (legal culture). Menurut Muladi, sistem peradilan pidana, sesuai dengan makna dan ruang lingkupnya, dapat bersifat fisik dalam arti sinkronisasi struktural (struktural syncronization), dapat pula bersifat substansial (substancial syncronization) dan dapat pula bersifat kultural (cultural syncronization). Dalam hal sinkronisasi struktural keserempakan dan keselarasan dituntut dalam mekanisme administrasi peradilan pidana dalam kerangka hubungan antar lembaga penegak hukum. Dalam hal sinkronisasi substansial maka keserempakan ini mengandung makna baik vertikal maupun horizontal dalam kaitannya dengan hukum positif yang berlaku. Sedang sinkronisasi kultural mengandung usaha untuk selalu serempak dalam menghayati pandangan-pandangan, sikap-sikap dan falsafah yang secara menyeluruh mendasari jalannya sistem peradilan pidana. ${ }^{24}$ Dengan demikian, keserempakan (syncronization) tersebut memberi kesamaan persepsi bagi semua tingkatan lembaga dan penegak hukum dalam memahami kasus-kasus yang berkaitan dengan perempuan dan isu kesetaraan gender.

Di dalam sistem peradilan pidana terdapat adanya suatu mekanisme input-processoutput. Adapun yang dimaksud dengan input adalah laporan/pengaduan tentang terjadinya tindak pidana. Process adalah sebagai tindakan yang diambil pihak Kepolisian, Kejaksaan, Pengadilan dan Lembaga Pemasyarakatan (sebagai empat sub-sistem

23 Ibid.

24 Ibid., hlm. 76-77. 
penegakan hukum). Sedangkan output adalah hasil-hasil yang diperoleh. ${ }^{25}$ Hasil inilah yang kemudian memerlukan evaluasi atau kontrol dari elemen-elemen masyarakat. Evaluasi ini sangat penting dilakukan sebagai ukuran dari nilai-nilai keadilan dalam masyarakat di mana aspek keadilan gender sudah menjadi perhatian publik di masa sekarang.

Dalam kasus Baiq Nuril sebagaimana disebut di atas, ada pandangan kritis atas putusan kasasi dari MA yang justru menghukum korban tindak pidana pelecehan seksual. Pandangan itu menyebutkan bahwa majelis hakim MA seharusnya berpedoman pada Peraturan Mahkamah Agung (Perma) Nomor 3/2017 tentang Pedoman Mengadili Perempuan Berhadapan dengan Hukum. Pasal 3 Huruf b peraturan tersebut menyatakan bahwa hakim mengidentifikasi situasi perlakuan tak setara yang berhadapan dengan hukum. Putusan atas Baiq Nuril, dan juga kasus-kasus pelecehan seksual lainnya, secara filosofis memperlihatkan kondisi adanya kekurangan atau ketidakcukupan aspek penilaian dan pertimbangan yang ada dalam putusan hukum itu, yaitu aspek kondisi kerentanan perempuan sehingga dia dengan mudah menjadi korban suatu tindak pidana.

Positivisme hukum sangat sering mengedepankan sisi prosedural dalam penegakan hukum yang dalam beberapa hal justru menyebabkan kaburnya aspek keadilan yang dituntut masyarakat. Dalam positivisme hukum, kepastian hukum hanya akan terwujud bila hukum dianggap sebagai sistem yang tertutup dan otonom dari berbagai persoalan moral, agama, filsafat, politik, sejarah dan semacamnya. Pertanyaan tentang keadilan, selama hukum itu masih berlaku, maka hukum tersebut tetap harus dipatuhi. Bagi para penganut positivisme hukum, kepastian hukum akan tercapai karena hukum dibentuk oleh lembaga yang berwenang dengan mengikuti sistem perundang-undangan yang berlaku, tanpa mempertimbangkan aspek nilai-nilai kesetaraan dan keadilan gender yang dianut oleh masyarakat.

Sebagai suatu sistem, di dalam mekanisme sistem peradilan pidana ada suatu syarat yang harus dipenuhi, yaitu adanya kerja sama di antara sub-sistem. Apabila salah satu subsistem tidak berjalan sebagaimana mestinya, maka hal itu akan mengganggu sistem secara keseluruhan. Karena itu, keempat sub-sistem itu (yakni Kepolisian, Kejaksaan, Pengadilan dan Lembaga Pemasyarakatan) memiliki hubungan yang erat satu dengan yang lainnya.

Berdasarkan pemaparan di atas, dapat digambarkan secara lebih detail bagaimana kebijakan hukum pidana dapat digunakan untuk membuat peraturan hukum pidana yang

25 Ibid. 
berkeadilan gender, yang meliputi kebijakan formulasi, kebijakan aplikasi, dan kebijakan eksekusi. Ketiga tahap penegakan hukum pidana tersebut, dilihat sebagai usaha atau proses rasional yang sengaja direncanakan untuk mencapai tujuan tertentu, jelas harus merupakan suatu jalinan mata rantai aktivitas yang tidak terputus yang bersumber dari nilai-nilai dan bermuara pada pidana dan pemidanaan. ${ }^{26}$

\section{Kebijakan Formulasi}

Kebijakan formulasi merupakan tahap perumusan kebijakan sebagai bagian dari proses legislasi suatu aturan perundang-undangan, sehingga kebijakan formulasi hukum pidana diartikan sebagai suatu usaha untuk membuat dan merumuskan suatu perundangundangan pidana yang baik. Tahap formulasi ini disebut juga dengan tahap penegakan hukum in abstracto oleh badan pembuat undang-undang, disebut juga sebagai tahap kebijakan legislatif. ${ }^{27}$

Kebijakan formulasi merupakan tahap yang paling strategis dari upaya pencegahan dan penanggulangan kejahatan melalui kebijakan hukum pidana. Kesalahan atau kelemahan kebijakan legislatif merupakan kesalahan strategis yang dapat menjadi penghambat upaya pencegahan dan penanggulangan kejahatan pada tahap aplikasi dan eksekusi. ${ }^{28}$

Kebijakan legislatif digunakan untuk mewujudkan hukum yang berperspektif gender dan mengutamakan keadilan gender. Undang-undang yang mengatur hukum pidana dapat dirancang menggunakan konsep khusus. Konsep khusus merupakan sebuah peraturan hukum pidana materiil yang bersifat khusus (lex specialis), artinya peraturan hukum pidana tersebut hanya mengatur perbuatan apa yang dianggap sebagai perbuatan pidana (kejahatan) seksual yang berbasis ketimpangan gender dan jenis sanksi terhadap pelakunya. Peraturan hukum pidana yang bersifat khusus ini juga harus mengatur tentang bagaimana proses penyidikan, penuntutan, sistem pembuktian, penanganan terhadap korban, perlindungan korban, dan persidangan, yang disebut sebagai hukum formil (hukum acara). ${ }^{29}$

26 Erdianto Effendi, Hukum Pidana Indonesia: Suatu Pengantar, cet. 2. Bandung: Refika Aditama, 2014, hlm. 33; Muladi, Kapita Selekta Sistem Peradilan Pidana. Semarang: Badan Penerbit Universitas Diponegoro, 1995, hlm. 13.

27 Barda Nawawi Arief, Kebijakan Legislatif dalam Penanggulangan Kejahatan dengan Pidana Penjara, cet. 3, Genta Publishing, Yogyakarta, 2010, hlm. 4.

28 Barda Nawawi Arief, Masalah Penegakan Hukum dan Kebijakan Hukum Pidana dalam Penanggulangan Kejahatan. Jakarta: Kencana Media Group, 2007, hlm. 75.

29 Sri Wiyanti Eddyono, “Dilema Reformasi Hukum Kekerasan Seksual dan Perlindungan Korban”, Kompas, 21 Agustus 2019, hlm. 7. 
Jika kekerasan seksual termasuk pemerkosaan dikategorikan sebagai hukum pidana umum (delik umum), maka hukum acaranya juga bersifat umum. Padahal salah satu titik permasalahan dalam penanganan kekerasan seksual yang berbasis ketimpangan gender adalah proses beracara kasus kekerasan seksual yang disandarkan pada prosedur beracara umum (lex generalis). Norma hukum acara pidana juga masih berorientasi kepada hak-hak tersangka dan terdakwa. Dalam Kitab Undang-Undang Hukum Acara Pidana (KUHAP), sama sekali tidak ada disinggung mengenai hak korban, tetapi hak tersangka dan terdakwa ada, yaitu hak didampingi penasihat hukum, dan sebagainya. Sedangkan hak korban sama sekali tidak diatur dalam KUHAP.

\section{Kebijakan Aplikasi}

Kebijakan aplikasi yaitu tahap penerapan hukum pidana oleh aparat penegak hukum mulai dari kepolisian, kejaksaan, sampai pengadilan, disebut juga sebagai tahap kebijakan yudikatif. Tahap aplikasi ini merupakan kekuasaan dalam hal menerapkan hukum pidana oleh aparat penegak hukum atau pengadilan, sehingga kebijakan ini disebut juga dengan kebijakan yudikatif. Proses akhir dari kebijakan yudikatif adalah putusan pengadilan. ${ }^{30}$

Mekanisme penegakan hukum oleh aparat penegak hukum harus berorientasi pada tujuan penyelenggaraan hukum sebagai suatu instrumen dari tertib sosial, dan proses pelaksanaan perlindungan kepentingan individu harus dalam rangka suatu sistem tertib sosial. Dengan demikian, eksistensi hukum dan pelaksanaannya tidak bersifat otonomi dan tertutup dari kehidupan masyarakat. ${ }^{31}$ Aparat hukum harus berpikiran terbuka dan memiliki kepekaan sosial saat menangani kasus-kasus tindak pidana yang berbasis ketimpangan gender, seperti kekerasan seksual.

Selama ini aparat penegak hukum secara umum belum memiliki perspektif gender. Aparat penegak hukum cenderung bias gender dan menyalahkan korban (blaming the victim). Kepekaan terhadap isu-isu gender belum menjadi wacana yang umum diketahui oleh aparat penegak hukum, sehingga reviktimisasi korban dalam proses hukum masih sering terjadi. Korban harus bercerita pengalaman traumanya tiga kali: kepada penyidik, kejaksaan, dan di pengadilan. Misalnya dalam persidangan, korban kekerasan seksual sering disalahkan, baik secara langsung maupun tidak langsung, dengan diberi pertanyaan

30 Syaiful Bakhri, Kejahatan Narkotika dan Psikotropika: Suatu Pendekatan Melalui Kebijakan Hukum Pidana, Bekasi: Gramata Publishing, 2012, hlm. 78.

31 Moh. Hatta, Kebijakan Politik Kriminal: Penegakan Hukum dalam Rangka Penanggulangan Kejahatan, Yogyakarta: Pustaka Pelajar, 2010, hlm. 3. 
seperti 'kenapa memakai rok pendek?'. Padahal memakai pakaian tertentu merupakan hak perempuan.

Di sinilah pentingnya kebijakan aplikasi, yaitu menerjemahkan aturan hukum yang sudah berperspektif gender ke dalam praktik penerapan oleh aparat penegak hukum yang juga harus berwawasan dan memiliki sensitivitas gender.

\section{Kebijakan Eksekusi}

Tahap ketiga dari kebijakan hukum pidana adalah tahap eksekusi, yaitu tahap pelaksanaan hukuman pidana secara konkret oleh aparat-aparat pelaksana pidana, disebut juga tahap kebijakan eksekutif atau administratif. Tahapan eksekutif atau administratif ini merupakan bagian dalam melaksanakan hukum pidana oleh aparat pelaksana/eksekusi pidana. $^{32}$ Perlakuan terhadap perempuan yang menjadi pelaku tindak pidana maupun korban tindak pidana harus didasarkan pada keadilan gender, sehingga wanita dapat bebas dari segala tindakan kekerasan dan diskriminasi. Korban kekerasan banyak terjadi pada perempuan, namun tentu pelaku tindak pidana juga dapat dari kalangan perempuan. Perlakuan pemerintah (lembaga eksekutif) terhadap perempuan yang berhadapan dengan hukum harus dilaksanakan dengan mempertimbangkan kondisinya sebagai perempuan yang memiliki karakteristik berbeda dengan laki-laki. Keadilan gender dalam kebijakan eksekutif merupakan bentuk perlindungan dari negara terhadap perempuan agar terhindar dan terbebas dari kekerasan atau ancaman kekerasan, penyiksaan, atau perlakuan yang merendahkan derajat dan martabat kemanusiaan.

\section{KESIMPULAN}

Berdasarkan pemaparan di atas, maka dapat disimpulkan bahwa pembaharuan hukum pidana nasional yang berkeadilan gender harus mempertimbangkan bukan hanya aspek filosofis dan ideologis, tetapi juga aspirasi yang tumbuh dalam masyarakat modern untuk memenuhi tuntutan ideal dan menjawab kenyataan sosial yang mengedepankan gender equality (kesetaraan gender). Oleh karena itu strategi pembaharuan hukum pidana nasional harus mampu merumuskan kebutuhan hukum masyarakat modern tersebut dalam rangka pencegahan dan penanggulangan kejahatan berbasis ketimpangan gender (tindak pidana kekerasan seksual).

32 Muladi, Kapita Selekta Sistem Peradilan Pidana, Semarang: Badan Penerbit Universitas Diponegoro, 1995, hlm. 13-14. 
Penanggulangan tindak pidana kekerasan seksual dapat dilakukan dengan sarana penal (penal policy) yang fungsionalisasi atau operasionalisasinya dilakukan melalui kebijakan formulasi (kebijakan legislatif), kebijakan aplikasi (kebijakan yudikatif), dan kebijakan eksekusi (kebijakan administratif). Kebijakan formulasi merupakan tahap paling strategis dari upaya penanggulangan kejahatan seksual dengan menggunakan sarana penal. Strategis dikarenakan pada tahap inilah ditetapkan pedoman-pedoman bagi pelaksanaan tahap-tahap selanjutnya, yaitu tahap aplikasi dan eksekusi. Dengan kata lain, kesalahan dalam membuat suatu formulasi peraturan perundang-undangan maka akan berdampak negatif bagi operasionalisasi dari aplikasi dan eksekusi peraturan tersebut. Kebijakan legislatif digunakan untuk mewujudkan hukum yang berperspektif gender dan mengutamakan keadilan gender. Undang-undang yang mengatur hukum pidana dapat dirancang menggunakan konsep khusus (lex specialist) yang mengatur tindak pidana kekerasan seksual, baik dari aspek hukum materiil maupun hukum formil (hukum acara). Adapun bagi kebijakan aplikasi, model pelaksanaannya dilakukan oleh aparatur hukum dan dapat bekerja sama dengan masyarakat, yang harus memiliki komitmen bersama dalam melawan segala bentuk tindak pidana yang berbasis ketimpangan gender. Sedangkan dalam kebijakan eksekusi, pemerintah dituntut untuk tegas dan tanpa ada sikap diskriminatif berdasarkan gender maupun pandangan yang merendahkan perempuan dalam melaksanakan tuntutan hukum yang telah diformulasikan maupun yang diputuskan oleh pengadilan, karena bagaimanapun sebagai Negara hukum pemerintah Indonesia harus memiliki keberanian dalam menegakkan peraturan dengan nilai-nilai yang berkembang dalam masyarakat kontemporer, yaitu nilai keadilan dan kesetaraan gender.

Sebagai bagian dari kebijakan perlindungan masyarakat, kebijakan hukum pidana bertujuan untuk melindungi terlaksananya kebijakan sosial. Sedangkan sebagai bagian dari kebijakan kriminal, kebijakan hukum pidana bertujuan untuk menanggulangi kejahatan dengan pendekatan pidana. Mengingat adanya saling keterkaitan antara tiaptiap kebijakan tersebut maka tujuan maupun landasan yang dipergunakan dalam kebijakan hukum pidana harus selaras dengan kebijakan sosial itu sendiri. Karena itu, dalam melakukan pembaruan kebijakan hukum pidana harus dilandasi dengan pertimbangan-pertimbangan yang cermat dan ilmiah berlandaskan pada nilai-nilai keadilan masyarakat. Keadilan masyarakat tersebut dapat tercermin dalam kontrol sosial atas putusan pengadilan, yang salah satunya adalah keadilan gender. 


\section{Daftar Pustaka}

\section{Buku}

Arief, Barda Nawawi, Bunga Rampai Kebijakan Hukum Pidana (Perkembangan Penyusunan Konsep KUHP Baru. Bandung: Citra Aditya Bakti, 2014.

Arief, Barda Nawawi, Kebijakan Legislatif dalam Penanggulangan Kejahatan dengan Pidana Penjara, cet. 3, Genta Publishing, Yogyakarta, 2010.

Arief, Barda Nawawi, Masalah Penegakan Hukum dan Kebijakan Hukum Pidana dalam Penanggulangan Kejahatan. Jakarta: Kencana Media Group, 2007.

Arief, Barda Nawawi, Masalah Penegakan Hukum dan Kebijakan Hukum Pidana dalam Penanggulangan Kejahatan. Jakarta: Kencana Media Group, 2007.

Arief, Barda Nawawi, RUU KUHP Baru Sebuah Resrukturisasi/Rekonstruksi Sistem Hukum Pidana Indonesia. Semarang: Badan Penerbit Universitas Diponegoro, 2009.

Bakhri, Syaiful, Kejahatan Narkotika dan Psikotropika: Suatu Pendekatan Melalui Kebijakan Hukum Pidana, Bekasi: Gramata Publishing, 2012.

Effendi, Erdianto, Hukum Pidana Indonesia: Suatu Pengantar, cet. 2. Bandung: Refika Aditama, 2014.

Friedman, Lawrence M., Sistem Hukum Perspektif Ilmu Sosial, cet. 7, terj. M. Khozim. Bandung: Nusamedia, 2015.

Hatta, Moh., Kebijakan Politik Kriminal: Penegakan Hukum dalam Rangka Penanggulangan Kejahatan, Yogyakarta: Pustaka Pelajar, 2010.

Lamintang, P.A.F. dan Theo Lamintang, Hukum Penitensier Indonesia, edisi ke-2, cet. 2. Jakarta: Sinar Grafika, 2012.

Maula, Bani Syarif, Sosiologi Hukum Islam di Indonesia: Studi tentang Realitas Hukum Islam dalam Konfigurasi Sosial dan Politik. Malang: Aditya Media Publishing, 2010.

Mudzakir, Posisi Hukum Korban Kejahatan dalam Sistem Peradilan Pidana. Disertasi, Jakarta: Program Pascasarjana Fakultas Hukum Universitas Indonesia, 2001.

Mudzakir, Posisi Hukum Korban Kejahatan dalam Sistem Peradilan Pidana. Disertasi, Jakarta: Program Pascasarjana Fakultas Hukum Universitas Indonesia, 2001.

Muladi dan Barda Nawawi Arief, Teori-Teori dan Kebijakan Pidana, cet. 4. Bandung: Alumni, 2010.

Muladi, Kapita Selekta Sistem Peradilan Pidana, Semarang: Badan Penerbit Universitas Diponegoro, 1995. 
Savitri, Niken, HAM Perempuan Kritik Teori Hukum Feminis Terhadap KUHP, Jakarta: Refika Aditama, 2008.

Sudarto, Hukum Pidana dan Perkembangan Masyarakat. Jakarta: Sinar Baru, 1983.

\section{Jurnal}

Ariyanti, Vivi, "Implementasi Asas Legalitas dan Retroaktif tentang Tindak Pidana Korupsi dalam Perspektif Hukum Islam”, Al-Manahij: Jurnal Kajian Hukum Islam, 9(1), 2015. Ariyanti, Vivi, “Konsep Perlindungan Korban dalam Sistem Peradilan Pidana Nasional dan Sistem Hukum Pidana Islam", Al-Manahij: Jurnal Kajian Hukum Islam, 13 (1), 2019.

Fineman, Martha A., "Feminist Legal Theory", Journal of Gender, Social Policy and the Law, Vol. 13 No. 1, 2015.

Ismayawati, Any, “Urgensi Nilai-nilai Religius dalam Pembaharuan Konsep Penanggulangan Pelacuran”, Al-Manahij: Jurnal Kajian Hukum Islam, 5 (2), 2011.

Mudzakir, "Kedudukan Korban Tindak Pidana dalam Sistem Peradilan Pidana Indonesia Berdasarkan KUHP dan RUU KUHP”, Jurnal Ilmu Hukum, 14(1), 2011.

Sulistyawan, Aditya Yuli, "Feminist Legal Theory dalam Telaah Paradigma: Suatu Pemetaaan Filsafat Hukum”, Jurnal Masalah-Masalah Hukum, Vol. 47, No. 1, Januari 2018.

\section{Artikel}

Eddyono, Sri Wiyanti, “Dilema Reformasi Hukum Kekerasan Seksual dan Perlindungan Korban”, Kompas, 21 Agustus 2019.

Tjandra, W. Riawan, “Mengukur Rasa Keadilan Putusan Kasus Baiq Nuril”, Kompas, 17 Juli 2019. 